\title{
Solid Phase Extraction and Spectrophotometric Determination of Mercury in Tobacco and Tobacco Additives with 5-( $p$-Aminobenzylidene)-Thiothiorhodanine
}

\author{
Weizhu Yang, ${ }^{a, b, c}$ Qun $\mathrm{Hu}^{b, c}$ Jing Ma, Liming Wang, ${ }^{b}$ Guangyu Yang ${ }^{*, a}$ and Gang Xie, \\ ${ }^{a}$ Department of Chemistry, Yunnan University, Kunming, 650091, P.R. China \\ ${ }^{b}$ School of Materials \& Metallurgy, Kunming Science and Technology University, Kunming, 650031, P.R. China \\ ${ }^{c}$ Yunnan Academy of Tobacco Science, Kunming 650106, P. R. China
}

\begin{abstract}
Foi desenvolvido um método altamente sensível, seletivo e rápido para a determinação de mercúrio, a partir da reação rápida de mercúrio(II) com 5-( $p$-aminobenzilideno)-tiorodanina (ABTR) e posterior extração em fase sólida do quelato colorido, utilizando discos $\mathrm{C}_{18}$. Em pH 3,5 e na presença do emulsificante-OP, ABTR reage com mercúrio(II) para formar um quelato vermelho na razão molar 1:2 (mercúrio:ABTR). O quelato foi enriquecido pela extração em fase sólida com discos $\mathrm{C}_{18}$ e o quelato retido, eluído com dimethyl formamida (DMF). Um fator de enriquecimento na ordem de 50 foi obtido. Em DMF, a absortividade molar do quelato é $1,21 \times 10^{5} \mathrm{~L} \mathrm{~mol}^{-1} \mathrm{~cm}^{-1} \mathrm{a}$ $545 \mathrm{~nm}$, e a lei de Beer é obedecida no intervalo $0,01 \sim 3 \mu \mathrm{g} \mathrm{mL}^{-1}$ na solução medida. O desvio

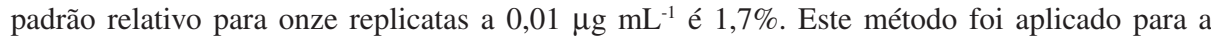
determinação de mercúrio em tabaco e aditivos de tabaco. Bom coeficiente de preconcentração foi encontrado, comparando-se o método proposto com outros similares.
\end{abstract}

A highly sensitive, selective and rapid method for the determination of mercury based on the rapid reaction of mercury(II) with 5-( $p$-aminobenzylidene)-thiorhodanine (ABTR) and the solid phase extraction of the colored chelate with $\mathrm{C}_{18}$ disks has been developed. At $\mathrm{pH} 3.5$ and in the presence of emulsifier-OP medium, ABTR reacts with mercury(II) to form a red chelate of a 1:2 (mercury to ABTR) molar ratio. This chelate was enriched by solid phase extraction with $\mathrm{C}_{18}$ disks and the retained chelate eluted form the disks with dimethyl formamide (DMF). An enrichment factor of 50 was achieved. In the DMF medium, the molar absorptivity of the chelate is $1.21 \times 10^{5} \mathrm{~L}$ $\mathrm{mol}^{-1} \mathrm{~cm}^{-1}$ at $545 \mathrm{~nm}$, and Beer's law is obeyed in the $0.01 \sim 3 \mu \mathrm{g} \mathrm{mL}^{-1}$ range in the measured solution. The relative standard deviation for eleven sample replicate measurements at the $0.01 \mu \mathrm{g} \mathrm{mL}^{-1}$ level is $1.7 \%$. This method was applied to the determination of mercury in tobacco and tobacco additives and good preconcentration was found between proposed and comparative methods results.

Keywords: mercury, solid phase extraction, spectrophotometry, 5-( $p$-aminobenzylidene)thiothiorhodanine

\section{Introduction}

Mercury is a toxic heavy metal. Thus, trace mercury determination in tobacco and tobacco additives is a very important issue. The Quality Standards of Tobacco in Chinese Tobacco Company says that the concentration of mercury should not exceed $0.2 \mu \mathrm{g} \mathrm{g}^{-1}$ in tobacco and tobacco additives. ${ }^{1}$ Many sensitive instrumental techniques, such as spectrofluorimetry, X-ray fluorescence spectrometry, neutron activation analysis, atomic absorption spectrometry, chemiluminescence, electrochemical analysis, and other have

*e-mail: ygy1110@163.com been widely applied to the determination of mercury. ${ }^{2-8}$ However, the spectrophotometric method has still the advantage of its simplicity and accessibility, not needing expensive or complicated equipments. For this reason, a wide variety of spectrophotometric methods for the determination of mercury have been reported. ${ }^{9-19}$ Each chromogenic system has its advantages and disadvantages with respect to sensitivity, selectivity and analysis speed.

Nevertheless, for the routine spectrophotometric determination of mercury trace, a preconcentration step is usually required. Solid phase extraction is attractive technique because of its notable advantages, namely simplicity and high pre-concentration factors. ${ }^{20-24}$ In the 
present work, a new chromogenic reagent, 5-( $p$ aminobenzylidene)-thiothiorhodanine (ABTR) was synthesized, and its reaction with mercuric ions and solid phase extraction of the formed chelate with $\mathrm{C}_{18}$ disks were studied. Based on this, a highly sensitive, selective and rapid method for the determination of total mercury in tobacco and tobacco additives was developed.

\section{Experimental}

\section{Apparatus}

An UV-2401 spectrophotometer (Shimadzu, Japan), equipped with $1 \mathrm{~cm}$ microcells $(0.5 \mathrm{~mL})$ was used in all absorbance measurements. The $\mathrm{pH}$ measurements were made with a Beckman $\Phi-200 \mathrm{pH}$ meter (Beckman Instruments, USA). The extraction was performed with a Waters Solid Phase Extraction (SPE) Device (Water Corporation, USA), and Zorbax $\mathrm{C}_{18}$ membrane disks $(47 \mathrm{~mm}$ (diameter) $\times 0.5 \mathrm{~mm}$ (thickness), $8 \mu \mathrm{m}, 50$ $\mathrm{mg}$ ) (Agilent Technologies, USA) were also used. A microwave oven (Model WL 5001, 1000W, Fei Yue Analytical Instrument Factory, Shanghai, China) equipped with PTFE high-pressure microwave aciddigestion vessels (Fei Yue, Analytical Instrument Factory, Shanghai, China) was used.

\section{Reagents}

The ABTR was synthesized by the following procedure: $40 \mathrm{~mL}$ of acetic acid was added to $1.5 \mathrm{~g}$ of thiorhodanine and $1.2 \mathrm{~g}$ of $\mathrm{p}$-aminobenzaldehyde, and the mixture was gently heated until total dissolution. The solution was refluxed for about $1.5 \mathrm{~h}$, and $1 \mathrm{~mL}$ of concentrated sulfuric acid was added dropwise. After the solution has turned red, the reflux was stopped and the sample was poured into $200 \mathrm{~mL}$ of distilled water. After the precipitation of a red solid took place, a small amount of aqueous ammonia was added. The solid was separated by filtration. They were recrystallized twice from absolute alcohol and the yield was $36 \%$ (mp $282 \sim 285{ }^{\circ} \mathrm{C}$ ). The structure (Figure 1) has been characterized by elemental analysis, IR, ${ }^{1} \mathrm{H}$ NMR and MS. Elemental analysis, found: C, 47.23; H, 3.28; N, 11.02; S, 37.53. Calc.for $\mathrm{C}_{10} \mathrm{H}_{8} \mathrm{~S}_{3} \mathrm{~N}_{2}$ : C, 47.59; H, 3.19; N, 11.10, S, 38.12\%. IR (KBr) $v_{\max }$ I $\mathrm{cm}^{-1}$ : 3470, 3450, $3355(\mathrm{~N}-\mathrm{H})$; 3060, $3020(\mathrm{C}-\mathrm{H}) ; 1628$ $(\mathrm{N}-\mathrm{H}) ; 1566,1548,1515,1450(\mathrm{C}=\mathrm{C}) ; 1292(\mathrm{C}-\mathrm{N}) ; 1171$ $(\mathrm{C}=\mathrm{S}) ; 825(\mathrm{Ar}-\mathrm{H}) ; 806(\mathrm{C}=\mathrm{C}-\mathrm{H}) .{ }^{1} \mathrm{H}$ NMR $\left(\mathrm{DMSO}_{-} \mathrm{d}_{6}\right) \delta$ 7.46 (s, 1H, C=C-H); 7.26, 7.35 (d, 2H, $J$ 9Hz, H-2 and $\mathrm{H}-6$ ); 6.62, 6.72 (d, 2H, J 9Hz, H-3 and H-5); 3.36 (w, $\left.2 \mathrm{H},-\mathrm{NH}_{2}\right)$. EIMS $m / z, 252\left[\mathrm{M}^{+}\right]$.

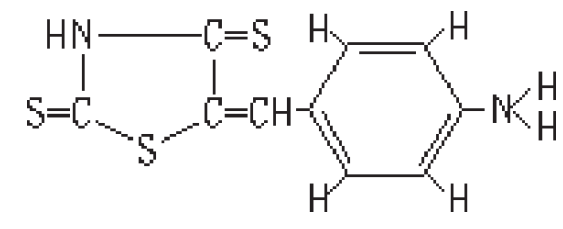

Figure 1. The structure of ABTR.

All of the solutions were prepared with ultra-pure water obtained from a Milli-Q50 SP Reagent Water System (Millipore Corporation, USA). High purity dimethyl formamide (DMF) (Fisher Corporation, USA) was used. A $3.0 \times 10^{-4} \mathrm{~mol} \mathrm{~L}^{-1}$ ABTR solution was prepared by dissolving ABTR in ethanol. A stock standard solution of mercury $\left(1.0 \mathrm{mg} \mathrm{mL}^{-1}\right)$ was obtained from the Chinese Standard Material Center, and a working solution $\left(0.5 \mu \mathrm{g} \mathrm{mL}^{-1}\right)$ was prepared by adequate dilutions of this solution. Sodium acetateacetic acid buffer solution ( $0.5 \mathrm{~mol} \mathrm{~L}^{-1}, \mathrm{pH} 3.5$, containing $0.2 \mathrm{~mol} \mathrm{~L}^{-1}$ of pyrophosphoric acid) was prepared by dissolving the $40.8 \mathrm{~g}$ sodium acetate, 180 $\mathrm{mL}$ acetic acid and and $44.2 \mathrm{~g}$ of sodium pyrophosphate in water and diluted to $1 \mathrm{~L}$. Emulsifier-OP solution $(2.0 \%, \mathrm{v} / \mathrm{v})$ was prepared by dissolving the emulsifierOP in water. All chemical used were of analytical grade unless otherwise stated.

\section{General procedure}

To a proper volume (up to $40 \mathrm{~mL}$ ) of standard or sample solution containing no more than $3.0 \mu \mathrm{g}$ of $\mathrm{Hg}$ (II), $5 \mathrm{~mL}$ of pH 3.5 buffer solution, $3.0 \mathrm{~mL}$ of $3.0 \times 10^{-4} \mathrm{~mol}$ $\mathrm{L}^{-1}$ ABTR solution and $2.0 \mathrm{~mL}$ of $2.0 \%$ Emulsifier-OP solution were added. The mixture was made up to $50 \mathrm{~mL}$ and well mixed. After $10 \mathrm{~min}$, the solution was passed through the $\mathrm{C}_{18}$ disks at a flow rate of $50 \mathrm{~mL} \mathrm{~min}^{-1}$. The elution was then performed at a flow rate of $5 \mathrm{~mL} \mathrm{~min}^{-1}$ in the reverse direction with $1.0 \mathrm{~mL}$ of DMF, and the final volume accurately made up to $1.0 \mathrm{~mL}$ in a $1.0 \mathrm{~mL}$ calibrated flask by adding microamounts of DMF with a $200 \mu \mathrm{L}$ syringes. The absorbance of this solution was measured at $545 \mathrm{~nm}$ in a $1 \mathrm{~cm}$ microcell $(0.5 \mathrm{~mL})$ against a reagent blank prepared in a similar way.

\section{Sample preparation}

The samples $(0.50 \mathrm{~g})$ were accurately weighted into the PTFE high-pressure microwave acid-digestion vessels, and $3.0 \mathrm{~mL}$ of concentrated nitric acid plus $5.0 \mathrm{~mL}$ of $30 \%$ hydrogen peroxide were added. The vessels were sealed tightly and then positioned in the carousel of the microwave oven. The system was operated at full power 
for $8.0 \mathrm{~min}$. The digest was evaporated to near dryness. The residue was dissolved with $5 \mathrm{~mL} 5 \%(\mathrm{~m} / \mathrm{v})$ nitric acid, and quantitatively transferred to a $50 \mathrm{~mL}$ volumetric flask for further analysis.

\section{Results and Discussion}

\section{Absorption spectra}

The absorption spectra of ABTR in water and its $\mathrm{Hg}$ (II) chelate in DMF are shown in Figure 2. The absorption peak maxima of ABTR in water and its complex in DMF medium are located at $420 \mathrm{~nm}$ and $545 \mathrm{~nm}$, respectively.

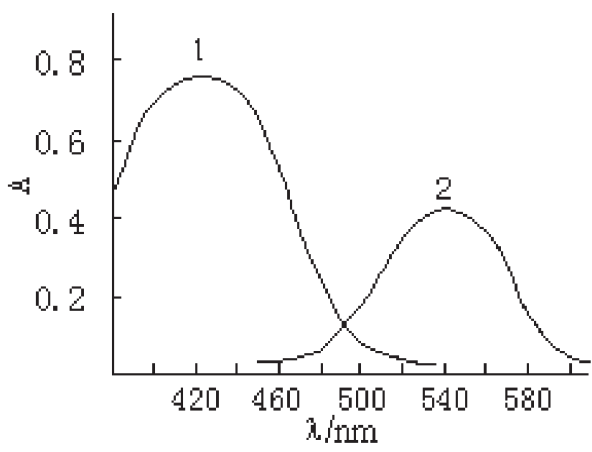

Figure 2. Absorption spectra of ABTR and its $\mathrm{Hg}(\mathrm{II})$ complex: 1) ABTREmulsifier-OP in water; 2) ABTR-Emulsifier-OP-Hg(II) chelate in DMF.

\section{Effect of acidity and masking}

Results showed that the optimal $\mathrm{pH}$ for the complexation of $\mathrm{Hg}$ (II) by ABTR is at the range 1.2 4.2. The use of the sodium acetate-acetic acid buffer solution $(\mathrm{pH} 3.5)$ is recommended, and the addition of $4 \sim 6 \mathrm{~mL}$ of this solution to a final volume of $50 \mathrm{~mL}$ was found to give a maximum and constant absorbance. A volume of $5 \mathrm{~mL}$ of the buffer solution was then recommended. The addition to the buffer solution of $0.15 \sim 0.25 \mathrm{~mol} \mathrm{~L}^{-1}$ pyrophosphoric acid do not affect the sensitivity and can greatly increase the selectivity. For instance, the tolerance limits of foreign ions such as $\mathrm{Cu}(\mathrm{II}), \mathrm{Ag}(\mathrm{I})$, $\mathrm{Pd}(\mathrm{II})$ and $\mathrm{Pb}(\mathrm{II})$, increased from $0.005,0.005,0.002$ and 0.002 to $0.5,0.2,0.1$ and $0.1 \mathrm{mg}$ per $50 \mathrm{~mL}$, respectively if pyrophosphoric acid is present. Thus, the presence of $0.2 \mathrm{~mol} \mathrm{~L}^{-1}$ of pyrophosphoric acid in the buffer solution is recommended.

\section{Effect of surfactants}

The influence of surfactants on the $\mathrm{Hg}$ (II)-ABTR chromogenic system was studied. The results (Table 1) showed that in the absence of surfactants, or in the presence both anionic or cationic surfactants, lower molar absorptivity $(\varepsilon)$ values were found, whereas in the presence of nonionic surfactants, the chromogenic system $\varepsilon$ values increases markedly. Considering the various nonionic surfactants invatigated the absorbance enhancement follows the sequence: Emulsifier-OP > Tween-80 > Tween-20 > Tween-60. Accordingly, the use of 0.5 3 mL of the Emulsifier-OP solution give a constant and maximum absorbance. The use of $2.0 \mathrm{~mL}$ of this surfactant was then recommended.

\section{Effect of ABTR concentration}

For up to $3.0 \mu \mathrm{g}$ of $\mathrm{Hg}(\mathrm{II})$, the use of about $3 \mathrm{~mL}$ of $3.0 \times 10^{-4} \mathrm{~mol} \mathrm{~L}^{-1}$ of ABTR solution has been found to be sufficient for a complete reaction. Accordingly, $3.0 \mathrm{~mL}$ of ABTR solution were added in all further measurement.

\section{Stability of the chromogenic system}

After mixing the components, the absorbance reaches its maximum within $5 \mathrm{~min}$ at room temperature and remains stable for at least $8 \mathrm{~h}$. After extracted into the DMF medium, the chelate was stable for at least $12 \mathrm{~h}$.

\section{Solid phase extraction}

Both the enrichment and elution were carried out on a Waters SPE device (able to prepare twenty samples simultaneously). The flow rate was set to $50 \mathrm{~mL} \mathrm{~min}^{-1}$

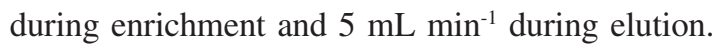

Some experiments were carried out in order to investigate the retention of $\mathrm{ABTR}$ and its $\mathrm{Hg}$ (II) chelate on the disks. It was found that the ABTR and its $\mathrm{Hg}$ (II) chelate could be quantitatively retained on the disks as they pass through the disks in aqueous solution. The capacity of the disks was determined as $30 \mathrm{mg}$ for ABTR and $25 \mathrm{mg}$ for its $\mathrm{Hg}$ (II) chelate both in $50 \mathrm{~mL}$ solution. This experiment has shown that the disks have adequate capacity to enrich the $\mathrm{Hg}(\mathrm{II})-\mathrm{ABTR}$ chelate to adequate levels.

Table 1. The effect of surfactants on $\mathrm{Hg}$ (II)-ABTR chromogenic system

\begin{tabular}{|c|c|c|c|c|c|c|c|c|}
\hline Surfactant & Absence & Emulsifier-OP & Tween-80 & Tween-20 & Tween-60 & SDS & СТМАВ & $\mathrm{CPB}$ \\
\hline$\lambda_{\max } /(\mathrm{nm})$ & 520 & 545 & 540 & 540 & 535 & 530 & 530 & 530 \\
\hline$\varepsilon /\left(10^{4} \mathrm{~L} \mathrm{~mol}^{-1} \mathrm{~cm}^{-1}\right)$ & 6.67 & 12.1 & 11.2 & 9.86 & 8.76 & 5.92 & 6.33 & 6.76 \\
\hline
\end{tabular}


In order to choose a proper eluent for the retained ABTR and its $\mathrm{Hg}(\mathrm{II})$ chelate, various organic solvents were studied. Their effectivences was evaluated and the following sequence was obtained: DMF $>$ acetonitrile $>$ acetone $>$ ethanol $>$ methanol. So DMF was selected as eluent. Experiments have shown that it is easier to elute the retained ABTR and its $\mathrm{Hg}$ (II) chelate in the reverse direction in comparison to the forward direction. Thus, it is also recommended to invert the disks before elution. Only $1.0 \mathrm{~mL}$ of eluent was sufficient to elute all the ABTR and its $\mathrm{Hg}(\mathrm{II})$ chelate retained at the disks at a flow rate of $5 \mathrm{~mL} \mathrm{~min}^{-1}$.

\section{Figures and merit}

The calibration curve showed that the Beer's law is obeyed in the 0.01 to $3 \mu \mathrm{g} \mathrm{Hg}$ (II) per $\mathrm{mL}$ concentration range. The linear regression equation obtained was $A=0.581 C\left(\mu \mathrm{g} \mathrm{mL}^{-1}\right)+0.0126(r=0.9994)$. The molar absorptivity was calculated to be $1.21 \times 10^{5} \mathrm{~L} \mathrm{~mol}^{-1} \mathrm{~cm}^{-1}$ at $545 \mathrm{~nm}$. The relative standard deviation $(\mathrm{n}=11)$ at a 0.01 $\mu \mathrm{g} \mathrm{mL}^{-1}$ concentration level was $1.7 \%$. The detection limit, based on the three times of standard deviation is $0.02 \mu \mathrm{g}$ $\mathrm{L}^{-1}$, in the original sample solutions.

\section{Composition of the chelate}

The composition of the complex was determined by the continuous variation (Figure 3) and molar ratio (Figure 4) methods. Both showed a $1: 2 \mathrm{Hg}$ (II) to ABTR molar ratio. A possible chelate structure is suggested in Figure 5.

\section{Interferences}

The selectivity of the proposed method was investigated by analysis of $20 \mu \mathrm{g} \mathrm{L}^{-1} \mathrm{Hg}$ (II) solutions containing various potentially interfering ions. A relative deviation of $\pm 5 \%$ was tolerated and the results are given in Table 2. The results showed that the ions commonly

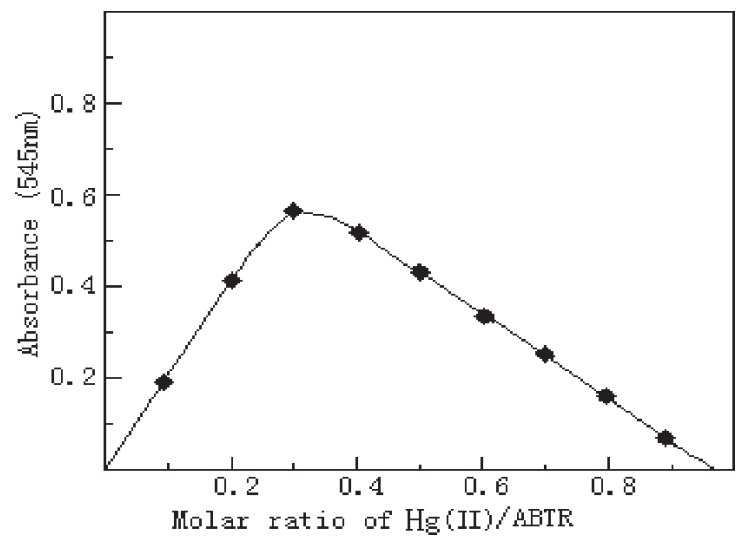

Figure 3. Composition of $\mathrm{Hg}(\mathrm{II})-\mathrm{ABTR}$ complex by continuous variation method. $\mathrm{Hg}(\mathrm{II})+\mathrm{ABTR}$ concentration: $1.2 \times 10^{5} \mathrm{~mol} \mathrm{~L}^{-1}$; other conditions as in standard procedure.

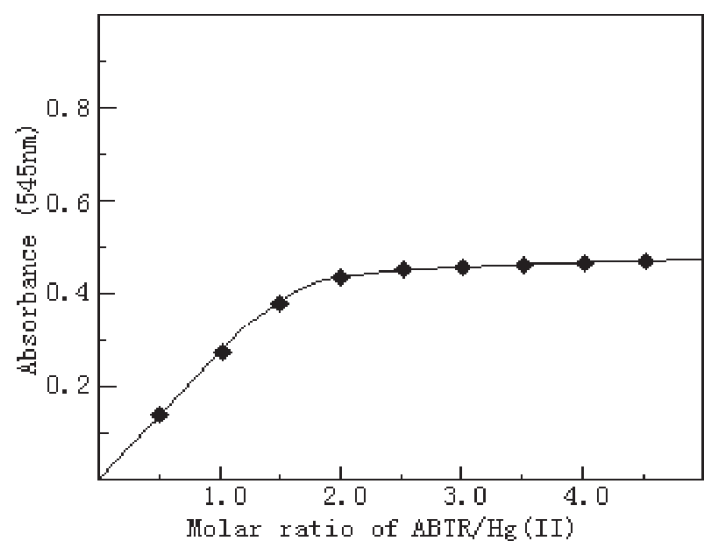

Figure 4. Composition of $\mathrm{Hg}(\mathrm{I} 1)-\mathrm{ABTR}$ complex by molar ratio method. $\mathrm{Hg}$ (II) concentration: $0.35 \times 10^{5} \mathrm{~mol} \mathrm{~L}^{-1}$; other conditions as in standard procedure.

present in $\mathrm{Hg}$ determinations do not interfere at a preoccupting concentration range.

\section{Application and validation}

The proposed method has been successfully applied to the determination of mercury in tobacco and tobacco additives. The digested sample was quantitatively

Table 2. Tolerance limits for the determination of $1.0 \mu \mathrm{g}$ of $\mathrm{Hg}(\mathrm{II})$ with $\mathrm{ABTR}$ (relative error $\pm 5 \%$ )

\begin{tabular}{ll}
\hline Ion added & Tolerance limit / (mg per 50 mL ) \\
\hline $\mathrm{NO}_{3}^{-}, \mathrm{K}^{+}$, borate, $\mathrm{Na}^{+}$ & 50 \\
$\mathrm{Li}^{+}, \mathrm{Al}^{3+}, \mathrm{PO}_{4}^{3-}, \mathrm{NO}_{2}^{-}, \mathrm{SO}_{4}^{2-}, \mathrm{ClO}_{4}^{-}$ & 20 \\
$\mathrm{Ca}^{2+}, \mathrm{Mg}^{2+}, \mathrm{SO}_{3}^{2-}, \mathrm{Sr}^{2+}, \mathrm{Ba}^{2+}, \mathrm{IO}_{3}^{-}, \mathrm{BrO}_{3}^{-}, \mathrm{ClO}_{3}^{-}$ & 10 \\
$\mathrm{Mn}^{2+}, \mathrm{Ce}(\mathrm{IV}), \mathrm{W}(\mathrm{VI}), \mathrm{Mo}(\mathrm{VI}), \mathrm{U}(\mathrm{IV}), \mathrm{Fe}^{3+}$ & 4 \\
$\mathrm{Ti}(\mathrm{IV}), \mathrm{Bi}(\mathrm{III}), \mathrm{V}(\mathrm{V}), \mathrm{Cr}(\mathrm{VI}), \mathrm{Zr}(\mathrm{IV}), \mathrm{F}^{-}, \mathrm{Fe}^{2+}, \mathrm{Cl}^{-}$ & 1 \\
$\mathrm{Cd}{ }^{2+}, \mathrm{Cr}^{3+}, \mathrm{La}{ }^{3+}, \mathrm{Sn}(\mathrm{IV}), \mathrm{Zn}^{2+}, \mathrm{Zr}(\mathrm{IV}), \mathrm{Co}^{2+}, \mathrm{Ni}^{2+}, \mathrm{Cu}^{2+}$ & 0.5 \\
$\mathrm{Ru}(\mathrm{III}), \mathrm{Bi}(\mathrm{III}), \mathrm{Pb}^{2+}, \mathrm{Sb}^{3+}, \mathrm{Th}(\mathrm{IV}), \mathrm{Br}^{-}, \mathrm{Os}\left(\mathrm{VIII}^{2}, \mathrm{I}^{-}\right.$ & 0.2 \\
$\mathrm{Se}(\mathrm{IV}), \mathrm{Te}(\mathrm{IV}), \mathrm{S}_{2} \mathrm{O}_{3}{ }^{2-}, \mathrm{Pd}^{+}, \mathrm{Ag}^{+}$ & 0.1 \\
$\mathrm{Ir}(\mathrm{IV}), \mathrm{Rh}(\mathrm{III}), \mathrm{Ru}(\mathrm{III})^{\mathrm{Pt}(\mathrm{IV}), \mathrm{Au}{ }^{3+}}$ & 0.05 \\
$\mathrm{CN}, \mathrm{SCN}$ & \\
\hline
\end{tabular}


Table 3. Determination of mercury in real samples

\begin{tabular}{lcccc}
\hline Samples & \multicolumn{2}{c}{ Mercury found $/\left(\mu \mathrm{g} \mathrm{g}^{-1}\right)$} & \multirow{2}{*}{ RSD \% / $(\mathrm{n}=5)$} & Recovery Range \% / $\mathrm{n}=5)$ \\
\cline { 2 - 4 } & Reference Method & This Method & 2.4 & $93-98$ \\
\hline Tobacco leaf (SA1) & 0.152 & 0.165 & 2.1 & $98-106$ \\
Tobacco leaf (SA2) & 0.186 & 0.197 & 2.3 & $97-105$ \\
Glycerol (AL) & 0.212 & 0.228 & 2.2 & $101-107$ \\
Tobacco sauce (AM) & 0.162 & 0.157 & 2.1 & $98-104$ \\
Cigarette (SF) & 0.217 & 0.232 & 2.5 & $94-102$ \\
Tobacco essence (AG) & 0.176 & 0.185 & \\
\hline
\end{tabular}

Table 4. The comparison reagents for the spectrophotometric determination of mercury

\begin{tabular}{|c|c|c|c|c|c|c|c|}
\hline Reagents & $\lambda_{\max } /(\mathrm{nm})$ & $\varepsilon /\left(10^{4}\right)$ & $\begin{array}{l}\text { Linear range / } \\
\text { (up to } \mu \mathrm{g} \mathrm{mL}^{-1} \text { ) }\end{array}$ & $\begin{array}{l}\text { Detect limit / } \\
\left(\mathrm{ng} \mathrm{mL} \mathrm{mL}^{-1}\right)\end{array}$ & Conditions & Interfering ions & Reference \\
\hline $\mathrm{H}_{2} \mathrm{Dz}$ & 485 & 7.1 & 2 & 1 & $\mathrm{pH} 2 \sim 5$, extraction $\mathrm{CHCl}_{3}$ & $\mathrm{Cu}, \mathrm{Zn}, \mathrm{Cd}, \mathrm{Pb}$ & 1 \\
\hline CPDAAB & 540 & 22.2 & 0.8 & 20 & alkaline medium, $\mathrm{pH} 10$ & $\mathrm{Co}, \mathrm{Zn}, \mathrm{Cd}, \mathrm{Ni}$ & 11 \\
\hline DAA & 514 & 22 & 0.8 & 2 & pH 9.0, Triton X-100 & $\mathrm{Cd}, \mathrm{Ag}, \mathrm{Pb}, \mathrm{Ni}$ & 13 \\
\hline BG & 625 & 59.6 & 00.5 & - & $\begin{array}{l}\mathrm{pH} 5 \text {, flotation of } \mathrm{Hg}-\mathrm{I}^{-}-\mathrm{BG} \\
\text { with cyclohexane }\end{array}$ & $\mathrm{Ni}$ & 14 \\
\hline CMPQ & 512 & 8.0 & 2 & 40 & $\mathrm{pH} 4 \sim 4.8$, Triton $\mathrm{X}-100$ & $\mathrm{Co}, \mathrm{Cu}, \mathrm{Pb}, \mathrm{Zn}, \mathrm{Ni}$ & 15 \\
\hline $\mathrm{TPPS}_{4}$ & 413 & 27.6 & 0.6 & 0.5 & $\begin{array}{l}\mathrm{pH} 8.0 \text {, heated in } 100{ }^{\circ} \mathrm{C} \\
\text { water bath for } 30 \text { nin }\end{array}$ & $\begin{array}{c}\mathrm{Mn}, \mathrm{Cu}, \mathrm{Ag}, \mathrm{Pb}, \mathrm{Fe}, \mathrm{Co} \\
\mathrm{Ni}, \mathrm{Zn}, \mathrm{Cd}, \mathrm{Mg}\end{array}$ & 16 \\
\hline PAR & 500 & 6.8 & 2 & 10 & $\mathrm{pH} 10$ & $\begin{array}{c}\mathrm{Cu}, \mathrm{Ni}, \mathrm{Co}, \mathrm{Fe}, \mathrm{Zn}, \mathrm{Ag} \\
\text { Cr, V, W, Mo, Mn }\end{array}$ & 17 \\
\hline NBS & 430 & - & 10 & 0.2 & nitric acid medium & $\mathrm{Cu}, \mathrm{Zn}, \mathrm{Cu}$ & 18 \\
\hline ABTR & 545 & 12.1 & 3 & 0.02 & pH 3.5, Emulsifier-OP & $\mathrm{CN}^{-}, \mathrm{SCN}^{-}$ & This Work \\
\hline
\end{tabular}

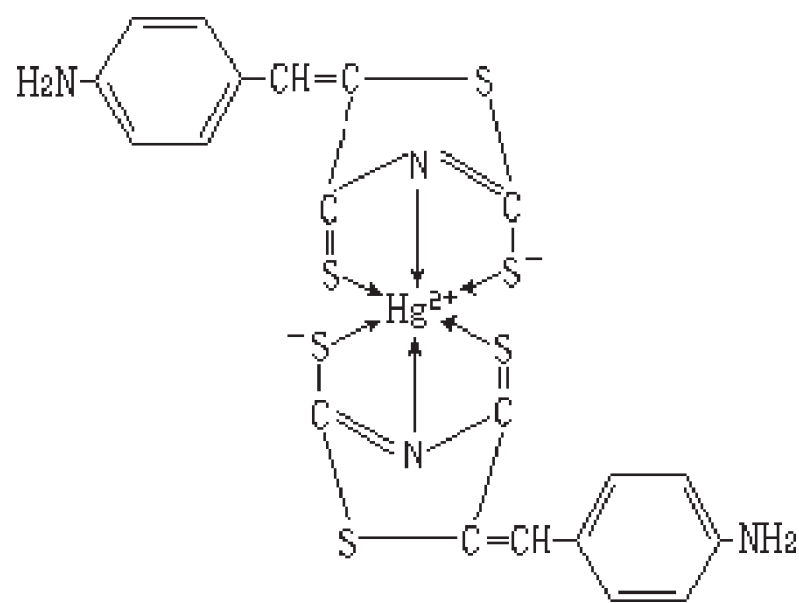

Figure 5. Proposed structure for the $\mathrm{Hg}(\mathrm{II})-\mathrm{ABTR}$ chelate.

transferred to a $50 \mathrm{~mL}$ of volumetric flask and analyzed by the proposed procedure. Recovery tests of $0.2 \mu \mathrm{g}$ mercury were carried out, as well as the parallel sample analysis by cold vapor atomic absorption spectrometry. ${ }^{1}$ The results are shown in Table 3.

\section{Conclusions}

A comparison of the proposed the ABTR method with other molecular absorptiometric methods (Table 4) shows that ABTR is a competitive spectrophotometric reagent for mercury determination. The molar absorptivity of the chelate reaches $12.1 \times 10^{4} \mathrm{~L} \mathrm{~mol}^{-1} \mathrm{~cm}^{-1}$, and no other system achieves this figure at the same low $\mathrm{pH}$ range. When masked with pyrophosphoric acid, most of the routine foreign ions do not interfere with the determination in the expected concentration range. By solid phase extraction of the ABTR-Hg(II) chelate with $\mathrm{C}_{18}$ disks, an enrichment factor of 50 as well as a detection limit is $0.02 \mu \mathrm{g} \mathrm{L}^{-1}$ in the sample solution were achieved. This is equivalent to $2 \times 10^{-3} \mu \mathrm{g} \mathrm{g}^{-1}$ in the original samples. The consum of organic solvents in this method is much lower than that observed in liquid-liquid extraction methods. Twenty samples can be prepared simultaneously. This is more rapid than that of routine method.

\section{References}

1. National Standard of Chinese Tobacco Company, Tobacco and Tobacco Additives, YB850-83, Chinese Standards Press, 1985

2. Wieteska, E.; Ziolek, A.; Chem. Anal. 2000, 45, 325.

3. Lu, I. Y.; Schroeder, W. H.; Water, Air, Soil Pollut. 1999, 112, 279.

4. Morita, M.; Edmonds, J. S.; Yoshinaga, J.; Pure Appl. Chem. 1998, 70, 1585.

5. Rose, M.; Owen, L.; Baxter, M.; Knaggs, M. A.; J. Anal. At. Spectrom. 2001, 16, 1101. 
6. Yang, G. Y.; Zhang, C. M.; Hu, Q. F.; Yin, J. Y.; J. Chromatogr. Sci. 2003, 4, 195.

7. Ellis, A. T.; Kregsamer, P.; Potts, P. J.; Streli, C.; West, M. Wobrauschek, P.; Holmes, M.; J. Anal. At. Spectrom. 1998, 13, 209R.

8. Abu Zuhri, A. Z.; Voelter, W.; Fresenius' J. Anal. Chem. 1998, 360,1 .

9. El-Sayed, A. Y.; Anal. Lett. 1998, 31, 1905.

10. Sang, M. P.; Hee-Seon, C.; Anal. Chim.. Acta 2002, 459, 75.

11. Chatterjee, S.; Pillai, A.; Gupta V. K.; Talanta 2002, 57, 461.

12. Gao, H. W.; Asian. J. Chem. 2000, 12, 78.

13. Chen, W. R.; Yang, W. F.; Yang, P.; Wang, W.; Chinese Chem. Reag (Ниахие Shiji) 1990, 12, 215.

14. Hu, Q. F.; Yang, G. Y.; Yin, J. Y.; Yao, Y.; Talanta 2002, 57, 751.

15. Mathew. L.; Reddy, M. L. P.; Iyer, C. S. P.; Damodaran, A. D.; Microchim. Acta 1997, 127, 125.

16. Kiwan, A. M.; EI-Shahawi, M. S.; Aldhaeri. S. M.; Saleh, M. H.; Talanta 1997, 45, 203.
17. Feng, Y. L.; Narasaki, H.; Tian, L. C.; Wu, S. M.; Chen, H. Y.; Anal. Sci. 1999, 15, 915.

18. Talanova, G. G.; Elkarim, N. S. A.; Talanov, V. S.; Bartsch, R. A.; Anal. Chem. 1999, 71, 3106.

19. Yallouz, A. V.; Calixto-De-Campos, R.; Paciornik, S.; Fresenius' J. Anal. Chem. 2002, 366, 461.

20. Garg, B. S.; Sharma, R. K.; Bhojak, N.; Mittal, S.; Microchem. J. 1999. 61, 94.

21. Pyrzynska, K.; Trojanowicz, M.; Crit. Rev. Anal. Chem. 1999, 29, 313.

22. Yang, G. Y.; Dong, X. C.; Hu, Q. F.; Yin, J. Y.; Anal. Lett. 2002, 35, 1735.

23. Keil, O.; Joachim, D.; Dietrich, A..V.; J. Chromatogr. Sci. 1997, $35,519$.

24. Haddad, P. R.; Doble, P.; Macka, M.; J. Chromatogr. A 1999, $856,145$.

Received: May 5, 2005

Published on the web: June 20, 2006 